\title{
'Around the axis of our real need': On the Ethical Point of Wittgenstein's Philosophy
}

\author{
Victor J. Krebs
}

'Working in philosophy [.. . ] is really more a working on oneself' - Wittgenstein

\section{Changing Aspects}

Twenty five years ago, Richard Rorty, commenting on the state of our understanding of Wittgenstein's legacy, wrote:

Academic philosophy in our day stands to Wittgenstein as intellectual life in Germany in the first decades of the last century stood to Kant. Kant had changed everything, but no one was sure just what Kant had said - no one was sure what in Kant to take seriously and what to put aside [...] Philosophers are in an analogous situation now [...] In this situation, a split has come about between [...] 'systematic linguistic philosophy' on the one hand and 'wittgensteinian philosophy' on the other. ${ }^{1}$

Rorty has a particular picture of what goes into this split, of what specific features of Wittgenstein's own philosophical development determine the distance that separates his later work from what goes on in the professionalized field of philosophy. In particular, he fully assumes the official account of the relation between the early and later work as itself providing an explanation of Wittgenstein's split from analytic philosophy. But none of it has anything to do with what, fifteen years later, Stanley Cavell pointed out as the one neglected feature of Wittgenstein's later work that he saw as marking the abyss separating him from professional philosophy. As he put it then,

even when the acceptance of Wittgenstein as one of the major philosophical voices in the West since Kant may be taken for granted, it is apt to be controversial to find that his reception by professional philosophy is insufficient, that the spiritual fervor or seriousness of his writing is internal to his teaching, say the manner (or method) to the substance, and that something in the very professionalization of philosophy debars professional philosophers from taking his seriousness seriously. ${ }^{2}$

What Cavell finds worth pointing out in the split separating Wittgenstein from institutionalized philosophy is a tone in his writing - a little understood aspect of 
his work which has been consistently neglected in the general picture of his later work, but which Cavell is here claiming may be essential to a deeper understanding of his teaching.

Both Cavell and Rorty were referring to the Investigations exclusively. But whereas Rorty rested his claims about that split on a conception of the Tractatus as itself a representative of precisely the perspective that had been left behind by the later work, Cavell was anxious to divorce his observation from that preconceived picture, in fact to neutralize - and even implicitly to question - the understanding of the Tractatus that is assumed in it, by remarking:

by 'Wittgenstein's philosophy' or 'Wittgenstein's teaching' I will always and almost always exclusively, mean what is contained in Philosophical Investigations. One may object to this procedure that one cannot understand that work without seeing it in its development from his Tractatus Logico-Philosophicus and from his work in the 1930's. That may be so, so may the reverse. ${ }^{3}$

In these words Cavell acknowledges the importance of the connection, but subtly resists aligning his reading of the Investigations to our common conception of the Tractatus, as if part of his thought were that the neglect he is pointing to may have infected our understanding of both and it may be necessary in the end to revise our common picture of the Tractatus in the light shed by the reconsideration of the Investigations that his remarks are intended to motivate.

Indeed, one of the most unsatisfactory features of the prevailing picture of the development of Wittgenstein's work is that it ignores, and so fails to account for, the deep continuity that exists between the two texts, precisely in the spiritual fervor of their writing, whose neglect in the Investigations Cavell is decrying. But attention to this aspect of the later work may shed new light on the relation between the early and the later philosophy and thus on the real nature of 'the split that has come about between "systematic linguistic philosophy" and "Wittgensteinian philosophy"'.

It is important, therefore, to note that when Cavell speaks of the distance between Wittgenstein and 'academic philosophy' his concern is very different from Rorty's. Rorty's understanding of this difference firmly stands within the context defined by the official picture and aims to characterize Wittgenstein's later philosophy on its basis. Cavell's remark, on the other hand, points to a diagnosis of the difference that belongs in a dimension of Wittgenstein's thought that has remained unexplored, not to say repressed, in the official picture presupposed by Rorty. By giving importance to an aspect of his thought which appears irrelevant or is even invisible from that perspective, it places the difference in a completely different category.

\subsection{Rorty's Wittgenstein}

Let me take a typical passage from Rorty characterizing his picture of Wittgenstein's later work to illustrate what I mean. This is from Contingency, Irony and Solidarity:

(C) Blackwell Publishers Ltd. 2001 
To drop the idea of languages as representations, and to be thoroughly Wittgensteinian in our approach to language, would be to de-divinize the world. [. . .] For as long as we think that 'the world' names something we ought to respect as well as cope with, something personlike in that it has a preferred description of itself, we shall insist that any philosophical account of truth save the 'intuition' that truth is 'out there'. This intuition amounts to the vague sense that it would be hybris on our part to abandon the traditional language of 'respect for fact' and 'objectivity' - that it would be risky, and blasphemous, not to see the scientist (or the philosopher, or the poet, or somebody) as having a priestly function, as putting us in touch with a realm which transcends the human. ${ }^{4}$

Rorty's rhetorical flourish sometimes shrouds the exact meaning of his words, but it is clear in this passage, I think, that for him Wittgenstein's later philosophy is essentially a critique of foundationalism; it is the rejection of a notion of absolute truth 'out there', and the abandonment of a search for essences or universals insofar as that search aims to deny or overcome the pure contingency of language. These elements are indeed central to Wittgenstein's later philosophy, and they are an integral part of what becomes for him not just a critique of foundationalism but a critique of scientism - in other words, a critique of the craving for theories and explanations, and the reductive spirit exemplified most poignantly for later Wittgenstein in the ideal of scientific knowledge. Rorty, however, takes the epistemological critique in the later work as leading to a rejection not just of the misguided attempts to articulate what the Tractatus called 'the transcendent', but also of the human need 'to be in touch with a realm that transcends the human', as Rorty puts it. But Wittgenstein himself distinguished in the 'Lecture on Ethics' the [nonsensical] attempts to articulate the transcendent (or 'the Ethical', as he calls it there) from the natural tendency that they manifest, clearly marking two different levels in his consideration. And whereas he admitted that the attempts did not add anything to our knowledge (in fact that they resulted in nonsensical statements), he affirmed emphatically that they were 'a document of a tendency in the human mind which I personally cannot help respecting deeply and I would not for my life ridicule it' ${ }^{5}$ Rorty not only ignores this distinction but takes Wittgenstein to have completely renounced his belief in the importance of that impetus. He thus misses, I believe, the real thrust or motivation of Wittgenstein's thought.

Abandoning our foundational urge means for Rorty that we must also abandon the supposedly naïve and illusory impression that "the world" names something we ought to respect as well as cope with'; or that, when we finally recognize that 'objectivity' and 'the facts' are not absolute, we must also give up the attempt to connect ourselves with 'a realm which transcends the human' as well as our sense that there is hybris in rejecting that aspiration. Wittgenstein's discovery, according to this reading, is that to think there is something more to the meaning of things than that which our own will and reason put there is nothing but the result of a faulty epistemology that leads us into superstition. As Rorty himself 
puts it elsewhere, describing the brand of voluntaristic pragmatism which he is intent on ascribing to later Wittgenstein:

There is nothing deep down inside us except what we have put there ourselves, no criterion that we have not created in the course of creating a practice, no standard of rationality that is not an appeal to such a criterion, no rigorous argumentation that is not obedience to our own conventions. ${ }^{6}$

Clearly, any appeal to the importance of the 'spiritual fervor' of Wittgenstein's writings in this context will sound a false note; it will not only appear philosophically irrelevant, but an embarrassing sign of the naïve and illusory urge or sense of higher values that Wittgenstein's later work is allegedly allowing us to overcome. But this is the result of seeing matters from a narrow epistemological perspective, which leads Rorty to conflate an attitude of respect towards the world, say a resistance to its instrumental reduction, with a false belief in its 'objectivity' understood in a foundational sense; as if - once we have abandoned our false foundational expectations - we could not still be inspired to awe by the pure contingency and unpredictability of the world. In other words, he reduces the issues raised by the human need for transcendence to an epistemologically foundational question, failing in this way to recognize that philosophical foundationalism is merely one of the multiple forms that that need can assume.

\subsection{Categorical Differences}

In his 'Remarks on Frazer's Golden Bough' Wittgenstein identifies this same reductionistic thinking in what he calls Frazer's 'spiritual narrowness', itself a product of the idolatry and scientific hybris that places the religious within the epistemological search for foundations, or subordinates the human need for transcendence to the instrumental impulse, and thus interprets its vocabulary or reads its behavior without having any sense of the real impetus that inspires it. In his inability to see the uses of language Wittgenstein considers except in terms of the issue of foundationalism, Rorty fails to recognize anything else in them than a stupid attachment to a false philosophical theory - just as Frazer could not see the ritual practices he was studying except as primitive and failed attempts at science, instead of recognizing them as a manifestation of deep and important dimensions of human experience. ${ }^{7}$ But one need only listen to the following comment, written by Wittgenstein toward the end of his life, to realize that his criticisms of science are meant as much more than a critique of foundationalism and that his ethical preoccupation is inseparable from his intellectual and argumentative concerns:

It isn't absurd [. . .] to believe that the age of science and technology is the beginning of the end of humanity; that the idea of great progress is a delusion, along with the idea that the truth will ultimately be known; that

(C) Blackwell Publishers Ltd. 2001 
there is nothing that is good or desirable about scientific knowledge, and that mankind, in seeking it, is falling into a trap. It is by no means obvious that this is not how things are. ${ }^{8}$

Ironically, then, this interpretation of Wittgenstein's critique of foundationalism leads us to a philosophical stance that is entirely alien - I would even say repugnant - to him, who rejects the ideal of scientific knowledge in his later work explicitly because it has separated us, as he is tempted to put it, 'from everything great, from God as it were'. ${ }^{9}$ In rejecting the attempt to seek in foundations an answer to our transcendental need, Wittgenstein is not - as Rorty would have it - also rejecting that need. Rorty is a clear example of what Cora Diamond has characterized as a reading of Wittgenstein's later philosophy that puts it in the service of the will not to be concerned with the ethical (in the sense that Wittgenstein meant by it) ${ }^{\prime} .{ }^{10}$ It is one of the tasks of this paper to specify the sense in which Wittgenstein meant 'the ethical', and thus to show the way in which Rorty's reading of the later philosophy is oblivious to it, how the perspective from which he interprets it makes Wittgenstein's real concern invisible. But suffice it to say here that when Cavell remarks that there is something about professional philosophy that prevents it from taking Wittgenstein's seriousness seriously, I believe he is pointing in the same direction.

The difference between Wittgenstein and Rorty lies on the level at which they are dealing with the issues involved. It reflects an attitudinal distance that cannot be saved by means of argumentation, since there is not an intellectual mistake in Rorty's reading as much as a categorical confusion, in Kierkegaard's sense when he claims that the scientific belongs in a different category from the ethical or the religious. What is needed is a change in perspective, a shift in the level or dimension of our consideration. As Wittgenstein himself phrased it in the remark from which I have culled the title of this paper, 'our consideration [Betrachtung] must be rotated but around the axis [Angelpunkt] of our real need', 11 so that 'the spiritual fervor or seriousness' of Wittgenstein's writing, for example, can sound to us like a true sign of a different philosophical intention rather than as a philosophical impertinence.

One of the obstacles to reading Wittgenstein in this way is found in the picture of the Tractatus offered by the Received Interpretation, which deaf in the same ways to the tone of Wittgenstein's writings, and blind to the essential unity of the style and the substance of the book, supports the epistemological narrowness exemplified in Rorty's reading of the later work. So I want to follow Cavell's suggestion and turn to the Tractatus, in order to consider it from the vantage point afforded by a deliberate attention to this aspect of Wittgenstein's work. ${ }^{12}$

\section{Towards a New Tractatus}

For several decades - beginning with Elizabeth Anscombe's ground-breaking Introduction to the Tractatus, which first appeared in 1959, followed at the end of the seventies by Peter Hacker's seminal Insight and Illusion - our picture of 
Wittgenstein's Tractatus Logico-Philosophicus seemed to have acquired a certain finality. It is not exaggerated to say that for all of us who studied the Tractatus before the decade of the nineties there were quite clearly defined parameters within which that work was understood and within which the discussion was carried on. According to what I am calling the Received Interpretation, the Tractatus was meant as a metaphysical or logical treatise, and it attempted to provide a theory that would enable us to finally draw the limits of language. The positivists initially took this to involve a rejection of all metaphysical talk as nonsense, but it quickly became evident - in part due to Wittgenstein's own pronouncements - that this involved a misunderstanding of his intention. As a result, what may be called the 'mystical' account of the doctrines in that book became the official picture of the work, according to which Wittgenstein did not reject metaphysical statements as empty but as failing attempts at 'saying' what were in fact ineffable truths. The Tractatus, it was held, nevertheless claimed to have managed in some way to show them to us through a peculiar practice of 'elucidation' which was exemplified in its text. Wittgenstein had thus provided in his early work the basis for a theory of linguistic representation that clearly marked the limits of meaningful language, and allowed us to effectively distinguish between significant propositions and nonsensical statements. From this latter group we could also distinguish between nonsensical statements that said nothing, and nonsensical statements that managed at least to point to, or show us, those ineffable truths about which, however - as the last pronouncement of the book admonished - we ought to remain silent.

It was only at the end of the eighties, that Cora Diamond and James Conant ${ }^{13}$ put forward a reading of the Tractatus that radically challenged some of the assumptions that had become hardened in the Received Interpretation. Conant and Diamond, primarily, - but also Juliet Floyd, ${ }^{14}$ Thomas Ricketts, ${ }^{15}$ Warren Goldfarb, ${ }^{16}$ and more recently Michael Kremer ${ }^{17}$ - have laid down a strong foundation for a new understanding of the Tractatus ${ }^{18}$ that has unleashed what may be the most vital activity and debate in the history of its interpretation - in any case certainly within the last twenty years.

Even if perhaps it has been until now the least explicitly developed feature of the New Reading, ${ }^{19}$ its most significant contribution for our understanding of Wittgenstein lies, I believe, in its ability to provide a more satisfactory answer to the question, so vexing to the Received Interpretation, ${ }^{20}$ about what Wittgenstein characterized as the book's ethical point in a letter to Ludwig von Ficker in 1919. These are his words:

The book's point is an ethical one. [...] My book draws limits to the sphere of the ethical from inside as it were, and I am convinced that this is the ONLY rigorous way of drawing those limits [. . . I have managed in my book to put everything firmly into place by being silent about it. ${ }^{21}$

According to the Received Interpretation the ethical point of the Tractatus is inseparable from the foundational task it claims that book is performing through

(C) Blackwell Publishers Ltd. 2001 
its mystical 'showing' of unsayable truths. And, as we have already seen with Rorty, it takes it to be overthrown or rejected by the critique of foundationalism advanced by the later work, so that the ethical point of the Tractatus almost imperceptibly - and inexplicably - falls out of view in the Investigations. But the New Reading not merely claims that the so-called critique of foundationalism ascribed to the later work is already performed by the Tractatus, but also shows that it is performed in the service of the ethical point of the book. Contrary to what the Received Interpretation rather implausibly suggests, Wittgenstein does not abandon his ethical concern in the later work; rather his whole philosophical practice, early and late, is an expression of it. As Cora Diamond puts it:

My suggestion is that we do not read the Tractatus well unless we see how its temper is opposed to the spirit of the times, and how it understands that spirit as expressed in connected ways in the idea of natural laws as explanatory phenomena in philosophy, and in relation to what Wittgenstein thinks of as ethics [...] whatever change there may have been in his approach to philosophy and to the treatment of philosophical illusion [in the later work] will not be a change that makes ethics fit our temperament. ${ }^{22}$

James Conant also adopts this perspective when he remarks that when Anscombe commented that the wild irrelevance of everything that had been written in the fifties about the Tractatus was caused by 'the neglect of Frege', ${ }^{23}$ she could not have been referring to an ignorance of the content of those works but to something more subtle than that. This is how Conant words it:

What more widely accepted platitude about the book could there be, than that it develops and responds to ideas put forward by Frege and Russell? [...] Anscombe's point [...] must rather be that we do not know who Frege is for the author of the Tractatus [. . . It is not that we are unfamiliar with Frege's or Wittgenstein's texts, but that we have failed to see what it is that is at issue in them. We fail to get hold of the questions which figure most centrally in these texts and of the kind of questions these questions are for Frege and for Wittgenstein. ${ }^{24}$

To know what was at stake, or what kind of questions these questions were for Frege and Wittgenstein, requires the same sensitivity, I believe, as is required to recognize the importance of the 'spiritual fervor' or 'seriousness' of Cavell's Investigations, or the 'temper' of Diamond's Tractatus.

The New Reading offers us a view of the Tractatus that takes seriously its claim to have an ethical point, to be ultimately a text written from an ethical perspective ${ }^{25}$ - a perspective that cannot but evaluate its intellectual efforts in terms of their significance to our conception of the human. This approach re-situates the question about the Tractatus' - and hence the Investigations' - true relation to analytical philosophy, by suggesting in fact that rather than renounce it - as for example 
Rorty (supported by the official picture itself) leads us to think - Wittgenstein may have followed it to its ultimate consequences in a way that has yet to be appreciated. ${ }^{26}$ In other words, contrary to Rorty's belief, Wittgenstein does not 'allow us to abandon philosophy' but - as Cavell has tirelessly insisted - to reinherit it, in a different shape: turning it around the axis of our real need.

\section{1 'Thinking Without Thoughts'}

Whereas the Received Interpretation taught us to see the Tractatus as a metaphysical or logical treatise that proposed doctrines and theories - however paradoxically - the New Reading denies that the book is at all meant to provide any positive teaching, if we understand by 'positive teaching' here a set of propositional truths intended to draw the limits of language. Not only does Wittgenstein not mean to give us any theories or doctrines but he intends to show us, or rather to make us acknowledge, that the propositions by which the Tractatus so meticulously purports to articulate them have only the appearance of meaning; that, as Wittgenstein puts it, 'the method of formulating [the problems of philosophy] rests on a misunderstanding of the logic of our language ${ }^{\prime},{ }^{27}$ so that in the Tractatus we are in the presence of a conception of philosophy that gives up the task of proposing theories in favor of a practice that aims for something more akin to self awareness, to a consciousness of the assumptions - particularly here the illusory assumptions - that underlie our theoretical claims. The New Reading suggests, in fact, that Wittgenstein is practicing in the early work what he described ten years later, when he wrote that '[in philosophy] one of the most important tasks is to express all false thought processes so characteristically that the reader says, 'Yes, that's exactly how I meant it'. To trace the physiognomy of every error' ${ }^{28}$ There is a shift in the aim of the philosophical task that points to what we might see as a concern for the psychological dimension and depth of philosophical illusion.

Already in the Preface, Wittgenstein sets up the context within which the book's exercise is to be understood. He clearly distinguishes his real aim: 'to draw a limit to the expression of thoughts', from what may be easily confused with it: 'to draw a limit to thinking'. Wittgenstein distinguishes these different aims only after having conflated them himself, thus showing how easily we may be inclined to slip into the confusion ourselves. Drawing limits to thinking is impossible, he tells us, for we would 'have to be able to think both sides of the limit'; we would have 'to be able to think what cannot be thought'. In fact, he adds, 'the limit [. . .] can only be drawn in language, and what lies on the other side of the limit will be simply nonsense'. So the book is left with the task of specifying what can be said, drawing the limit to the expression of thought, and this only in language or - as he puts it in the famous letter to von Ficker - from inside.

The fact that the Tractatus is not a text book - kein Lehrbuch - is essential to understanding what it means to draw limits to the expression of thought and not to thought itself, and to do so, besides, 'from inside'. That Wittgenstein emphasizes

(C) Blackwell Publishers Ltd. 2001 
'from inside' is important because it signals that he is fighting the illusion which, as Diamond says, he saw generalized in philosophy - that we can attain a perspective outside language. ${ }^{29}$ However, although he is implicitly warning us about the illusion in the Preface, warning us in a way that makes us aware of how natural it is for us to slip into it, he still needs to establish it as such. He needs to show us that any theory that purports to draw the limits of language rests on this illusion. The peculiarity of the text, moreover, is that he will do that not by presenting an argument, much less a theory, but by 'tracing the physiognomy of the error' involved, for, as Wittgenstein pointed out with characteristic psychological insight:

One must start out with error and convert it into truth. That is, one must reveal the source of error, otherwise hearing the truth won't do any good. The truth cannot force its way in when something else is occupying its place. To convince someone of the truth, it is not enough to state it, but rather one must find the path from error to truth. ${ }^{30}$

The book therefore abstains from proposing theories except in order to make them objects of scrutiny, to show through their means the 'misunderstanding of the logic of our language' upon which they stand. The Tractatus, then, as the New Reading argues, is a therapeutic text, the purpose of which is diametrically opposed to that of a traditional philosophical treatise: The positions the Tractatus puts forward, ${ }^{31}$ which have been traditionally taken to articulate Wittgenstein's own views, are presented in order to lead us to see that the task of providing a theory to delimit thought is impossible. ${ }^{32}$ Thus, the strategy of the Tractatus, according to Conant,

depends on the reader's provisionally taking himself to be participating in the traditional philosophical activity of establishing theses through a procedure of reasoned argument; but it only succeeds if the reader [undergoes the] experience of having his illusion of sense (in the 'premises' and 'conclusions' of the 'argument') dissipate through its becoming clear to him that (what he took to be) the philosophische Sätze of the work are Unsinn. ${ }^{33}$

The propositions of the Tractatus can be seen then, as 'paradigmatically failing attempts to delimit thought, language and reality'. ${ }^{34}$ Every time we think we have managed that aim we come to the realization, through our own thinking them through, that Wittgenstein's propositions are nonsensical. As Juliet Floyd explains:

The Tractatus aims to get us to see the nonsensicality of metaphysical debates about thought by seducing us into reading such accounts into its remarks, and then shocking us into a reassessment of the indefiniteness of our own thinking. It takes thinking to see [...] that Wittgenstein's 
Satzzeichen are not as they stand sinnvolle Sätze. One begins with this or that Satzzeichen and comes to see, by thinking, that it has no definite sense. For Wittgenstein there is thinking without thoughts. ${ }^{35}$

Floyd has persuasively argued that in Wittgenstein's remarks on mathematics one can often find discussions of the same essential issues that occupy him in his philosophical writings; that in fact his philosophical concerns always have their root or seminal intuitions in those discussions. So it is instructive to know that Wittgenstein believed that the classical proofs of impossibility provided a model in mathematics of how philosophical practice can help us get to the root of philosophical illusion. ${ }^{36}$ In fact, the exercise of the Tractatus may be seen itself as an analogous instance of an impossibility proof, where the actual steps by which we arrive at the conclusion are the means to discover that its intentions are impossible to fulfill. Take the so-called proof of the trisection of an angle, an example Wittgenstein used constantly in his discussions in mathematics. It is the conclusion of that proof that there is no such thing as the Euclidean trisection of an angle. In other words, the attempt to construct the trisection of an angle ends up demonstrating that, as a matter of fact, it is impossible to trisect an angle with straight-edge and compass as the Euclidean system would require, so that the search for such a trisection was an illusion, and 'Euclidean trisection of an angle' a string of words with no meaning, mere nonsense.

The Tractatus, Floyd's discussion suggests, works in the same way. It sets out to draw the limits of meaningful language and it leads us to realize that all the propositions by which it articulates the theory that purports to achieve that task are nonsensical, the very thought they articulate empty. Or, as Wittgenstein declares at the end of the book:

My propositions are elucidatory in the following way: he who understands me eventually recognizes them as nonsensical, when he has used them - as steps - to climb up beyond them. (He must, so to speak, throw away the ladder after he has climbed up it. $)^{37}$

\section{2 'Identifying two different things': Philosophical nonsense}

Interpreters of the Tractatus have admitted that Wittgenstein's propositions are indeed problematic, even paradoxical - pretending as they do, to provide criteria for meaningfulness that they themselves transgress and so are unable to satisfy. But under the assumption that the Tractatus is meant as a traditional philosophical treatise, interpreters have resisted taking him at his word, refusing to accept the theoretical propositions of the book to be simply nonsense, empty strings of words, as the New Reading insists we must do; and they have attempted instead, at all costs, to extract from the book a positive teaching. Cora Diamond has called this resistance to take Wittgenstein at his word 'chickening out'. It involves holding that our recognition of these propositions as nonsensical rests on our discerning

(c) Blackwell Publishers Ltd. 2001 
the specific logical necessities they have contravened in their attempt to articulate them; that in their very failure they are able to reveal to us the limits of meaningful language. By holding on to the expectation that Wittgenstein is providing theoretical means to draw the limits of thought, however, the Received Interpretation is simply holding on to the illusion he is intent on dispelling, for as Diamond points out, there is a clear idea here that there is something we cannot do which is shown by this transgression of logic, by these nonsensical statements. ${ }^{38}$ But when Wittgenstein calls his propositions nonsensical he means not that they fit some predetermined category, or fulfill some given criteria of nonsense, so that there is indeed something that we cannot do expressed or articulated in those criteria. He means, rather, that they have the false appearance of meaning something: that what we thought they said just vanished before our eyes, like a fantasy bubble bursts under the pressure of the facts.

Of course, it is natural to resist this conclusion for it is difficult to see what positive insight such an experience could provide us. Thus Peter Hacker, for instance, claims that according to Diamond's interpretation, the Tractatus 'was never meant to be a working clock, but a self-destructive one designed to explode as soon as wound up'. ${ }^{39}$ And Marie McGinn accurately articulates the same suspicion when she charges against the New Reading that if we take Wittgenstein at his word then the Tractatus simply ends up 'provid[ing] insights necessary for its own selfdestruction and [...] no genuine insight that is not ultimately obliterated in the final act of self-anihilation' ${ }^{40}$

The analogy with the proof for the impossibility of the trisection of an angle helps us to see, however, that contrary to what Hacker and McGinn object, the demonstration in the Tractatus does not end simply in empty self-annihilation. It is important to see that the proof of impossibility here is not just an ordinary proof. When we prove that it is impossible, for instance, to get to New York from here in less than one hour the proof is simple: we measure the distance, determine the fastest means of transportation available, factor all this information into our calculations, and conclude that it is impossible to get to New York in less than one hour. We are clear about what has been proved impossible. But the proof of impossibility Wittgenstein takes as a model for how to get to the root of philosophical illusion does not simply show us that ' $X$ ' is impossible, but also that we are unable to specify what this ' $X$ ' is that supposedly we cannot do, so that our initial idea was fatally flawed.

'By proving that it is impossible to trisect an angle by rule and compasses', Moore reports Wittgenstein to have said during his lectures in Cambridge in the 30's, 'we change a man's idea of trisection of an angle', adding that 'we should not say that what has been proved impossible is the very thing which we had been trying to do, because "we are willingly led in this case to identify two different things"' ${ }^{41}$ Wittgenstein's model, then, is meant to get us to see that the idea we originally had of what we were doing or attempting to do needs to be revised, but not because we have made a mistake in thinking we could do it, not because what we were thinking was propositionally false, but because what we thought we grasped was empty. Surely this is not a propositional insight, ${ }^{42}$ but that does not mean that it is not genuine or that it is purely destructive, as these objections assume. 
What the New Reading is suggesting and is missed by both Hacker's and McGinn's objections is that the elucidatory task of the Tractatus is not purely destructive, it does not end with our recognition of the nonsensicality of its propositions. The task merely begins there. As Diamond explains:

In recognizing that they are nonsense, you are giving up the idea that there is such a thing as understanding them. What Wittgenstein means by calling his propositions nonsense, is not that they do not fit into some official category of his of intelligible propositions but that there is at most the illusion of understanding them. ${ }^{43}$

The prize is not some propositional knowledge or insight but a recognition of emptiness in our thinking which immediately deflects our concern from the content of the propositions to the nature of this exercise in which we have been involved, this 'thinking without thoughts'. The issue shifts, in other words, from what we were thinking, which is seen to be empty, to how we [could have possibly] thought what we did. In this way Wittgenstein's method in the Tractatus changes the philosophical subject.

The fact that we are led to the realization that these propositions make no sense, not on the basis of a theoretical definition of nonsense to be grasped intellectually but in our actual experience with them, suggests that the original aim of the exercise is to exemplify an instance of false imagination rather than to establish logical incorrectness. By realizing in the practice that our attempts at drawing the limits of language don't add up, we are confronted with the experience of failure - that is, with the particular experience of our words strangely oscillating between meaningfulness and nonsensicality, making sense partially and then again not making sense, disappearing like a mirage, or appearing again as a paradox or a contradiction. But the practical nature of the proof dissolves the paradox, for it involves us in the actual process by which we are forced to think through the steps, not merely to intellectually grasp them, but to struggle with them until we recognize ourselves in them, realizing that we can imagine ourselves making sense at the same time that we know we don't. We are made privy, as it were, to another source of understanding than the merely intellectual, which allows us to see that what looked like an insoluble paradox is not a paradox at all: It is our assumption that in order to misunderstand a proposition there must be something to understand that leads us to ignore the fact that we can and in fact are imagining sense where there is none. Wittgenstein's propositions are elucidatory insofar as they lead us to see, not on the basis of a theoretical account, ${ }^{44}$ but as the conclusion of a demonstration - performed in the very exercise of 'thinking without thoughts' - that our original conception of our task is flawed. ${ }^{45}$

Like the geometrical proof, the exercise of the Tractatus illustrates the fact that being able to entertain a thought as [mathematically or logically] true does not tell us anything about whether the thought is even possible, whether it is a thought at all; that it is only in the actual context of the proof, in the application of its concepts, that we can arrive at the conclusion that what we were thinking does

(C) Blackwell Publishers Ltd. 2001 
not, in fact, have an application. It dissolves the illusion that we already knew, prior to the practice, how logic will play itself out in it; the illusion, that we use language from the perspective of a purely logical understanding that precedes our engagement with words in the actual context. It awakens us, in other words, from the false belief that we are logically omniscient, as Floyd puts it. ${ }^{46}$

The discovery that our propositions are nonsense shatters the illusion that we can stand outside logic to determine the limits of thought, by the simple fact that only in the actual practice, ${ }^{47}$ through the application of the rules in this concrete case, are we able to see whether these signs have meaning or not; not by means of criteria antecedently defined, but in language, from inside, through our spontaneous imaginative activity. ${ }^{48}$ So our failure to articulate meaningful propositions shows not that language is unable to give expression to the necessary grounds of meaning, but that there are no such grounds except what is the practice itself. ${ }^{49}$ As Ricketts writes:

The incoherence in Wittgenstein's rhetoric [...] draws us away from the illusory goal of saying what can only be shown to the activity of saying clearly what can be said, the activity of philosophy (4.112). In saying clearly what can be said, we serve the interests that had led us to aspire to a general description of the constitution of the world. In particular, by saying clearly what can be said, philosophy [. . . s should limit the unthinkable from within the thinkable (4.114). It will mean the unspeakable [das Unsagbare] by clearly displaying [darstellen] the speakable (4.115). ${ }^{50}$

Wittgenstein is not saying that these propositions are nonsense because they fail to satisfy certain given criteria of meaningfulness. Wittgenstein is rather showing us that they fail to say anything, and thus making us realize - through our own experience - that we don't know how to make them mean what [we thought we knew] we meant by them, that we have no idea what it would be for these propositions to say what we mean. It is precisely because there are no theoretical criteria, no sufficient conditions of meaning that we can foresee prior to their actual application, that we can deceive ourselves into thinking our propositions are meaningful. Thus Tractatus 4.003:

Most propositions and questions, that have been written about philosophical matters, are not false, but senseless. We cannot, therefore, answer questions of this kind at all, but only ascertain their nonsensicality [Unsinnigkeit]. Most questions and propositions of the philosophers rest on the fact that we do not understand the logic of our language. [. . .] And it is not too surprising that the deepest problems are really no problems.

\section{On Not 'Chickening Out': The Ethical Point of the Tractatus}

According to the New Reading, the aim of the Tractatus requires not just rational calculation or discursive reasoning but also, and primarily, an exercise of imagination. As Diamond puts it: 
To want to understand the person who talks nonsense is to want to enter imaginatively the taking of that nonsense for sense [...] the Tractatus [...] supposes a kind of imaginative activity, an exercise of the capacity to enter into the taking of nonsense for sense, of the capacity to share imaginatively the inclination to think that one is thinking something in it. ${ }^{51}$

Entering into the taking nonsense for sense, going as far as one can with the idea that there is something to understand, means empathically placing oneself in the context where empty thinking acquires the feel of meaningful thinking. But this, as we have already said, radically changes the subject. For the question refers us now to our own ability to self-deception and inquires into the causes of such a condition, as if philosophy found itself now forced to address issues of selfknowledge, ${ }^{52}$ matters of ethical consequence.

Rather than giving us new truths, these propositions are meant to redirect us into ourselves, to provide an insight into our relation with propositional truths. ${ }^{53}$ What the Tractatus teaches us is an existential or experiential truth - what Wittgenstein will later call a grammatical truth - about the way in which we use our words, about the way language is entwined with our practices in its everyday functioning. It shows us that there are mistakes that have to do with our failure to fix the meaning of our signs. As Conant puts it:

[...] Wittgenstein's teaching is that the problem lies not in the words (we could find a use for them), but in our confused relation to the words: in our experiencing ourselves as meaning something definite by them, yet also feeling that what we take ourselves to be meaning with the words makes no sense. ${ }^{54}$

So when Wittgenstein says that his propositions are elucidations, their elucidatory power, as Juliet Floyd has put it, is not in the dimension of assertion. ${ }^{55}$ It is in the realm of imagination. ${ }^{56}$ The teaching of the Tractatus is not merely about logic, or perhaps more accurately, it gives logic a new depth by not only engaging our intellectual powers of understanding but also by appealing to our ordinary sense of language, thus making the task of getting logic right an ethically imperative matter. It is by 'bringing more clearly into view for the reader the life with language he already leads' as Conant says, 'by harnessing the capacities for distinguishing sense from nonsense [...] implicit in the everyday practical mastery of language which the reader already possesses ${ }^{\prime 57}$ that it attains its aim. ${ }^{58}$ The Tractatus thus instantiates in its own practice the aim of revealing the sources of philosophical illusion by bringing the reader to a first hand understanding of what it is that moves her into empty talk, what process of false imagination, in other words, is involved in this instance of self-deception. It is this understanding, what we may now identify as the ethical inflection of his thought, that becomes central and is responsible for the radical shift of focus that takes place in philosophy for Wittgenstein. ${ }^{59}$

(C) Blackwell Publishers Ltd. 2001 


\subsection{Towards an Aesthetics of Speech}

In the Investigations Wittgenstein tells us that 'speech with and without thought is to be compared with the playing of a piece of music with and without thought' ${ }^{60}$ Meaningless thought and meaningless speech, like expressionless music, fail not in that they don't follow 'the rules' but in that what 'breathes life' into them is absent. Philosophical nonsense is not just a technical problem, but involves confusions in our relation with our own words and with the context in which we seek to articulate ourselves. The task it demands requires an effort to appropriate words as means of self-expression. As Wittgenstein writes:

People are deeply imbedded in philosophical, i.e. grammatical confu-
sions. And to free them from these presupposes pulling them out of the
immensely manifold connections they are caught up in. One must so to
speak regroup their entire language. - But this language came
about// developed// as it did because people had - and have - the incli-
nation to think in this way. Therefore pulling them out only works with
those who live in an instinctive state of rebellion against / / dissatisfaction
with// language. Not with those who following all of their instincts live
within the herd that has created this language as its proper expression.

One must be able to resist, Wittgenstein tells us, the inclination to think in certain ways that language feeds in us, in order to overcome the illusions of thought that lead us to the false problems and nonsensical propositions of philosophy. Wittgenstein's Tractatus may be seen then as part of his life-long reaction against our tendency to fall blindly into the traps of language, against our inclination in philosophy to think and talk emptily as a result of our assuming, in particular, that we can stand outside language and determine the conditions of meaningfulness independently of the practical effort of thinking our words through in the actual context of their use.

The theoretical stance criticized by the Tractatus, and the illusory assumption uncovered behind it, are means by which we avoid what Wittgenstein considered the path demanded by philosophy of coming to terms with oneself, of 'descending into our own chaos ${ }^{\prime 62}$ in order to breathe life into our words, instead of seeking to turn that task into a technical problem. There is in our attempt to draw the limits of language by means of theories a resistance to the existential confusion that unavoidably confronts us in language. And logical formalization or theorizing can become a means to do away with the very level of language where philosophical problems acquire their existential depth. It is true, therefore, that, as Conant points out, ${ }^{63}$ the search for perspicuity in our language is for Wittgenstein inseparable from a search for 'honesty' so that Diamond is not just being picturesque in her characterization of the resistance to take Wittgenstein at his word as 'chickening out'; there is indeed a kind of existential cowardice involved in it. For Wittgenstein it is an essential requirement for the philosophical work he 
proposes that we overcome our own 'powerful inclination to evade seeing the difficulties as the kind of difficulties they are' ${ }^{64}$ As I understand it, it is the insight into this inclination with its concomitant desire to stand outside language and avoid the task to think things through, that determines the ethical point of Wittgenstein's philosophy, both early and late.

The aim of the Tractatus, as Michael Kremer says, 'is to change our relationship to nonsense, to get us to stop wanting certain kinds of nonsense in certain kinds

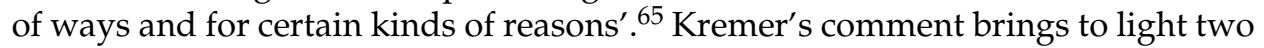
important points to bear in mind about Wittgenstein's position. In the first place, Kremer's observation that the Tractatus is meant to stop us from wanting certain kinds of nonsense, makes it clear that for Wittgenstein there are irrational attachments that philosophy is intended to free us from; that part of the philosophical battle - that part which occupies a great deal of the efforts of the Tractatus and, I would say, most of those of the later philosophy - is not so much against intellectual confusion as it is against emotional fixation. As Wittgenstein himself says,

philosophy requires a resignation, but one of feeling and not of intellect. And maybe that is what makes it so difficult for many. It can be difficult not to use an expression, just as it is difficult to hold back tears, or an outburst of anger. ${ }^{66}$

Philosophy therefore needs to consider its problems from another perspective than the merely theoretical; it needs to turn around the axis of our real need, as Wittgenstein puts it in the Investigations. That is something achieved in his writings through the systematic appeal to the imagination - practiced in its initial way in the exercise of the Tractatus as the New Reading makes evident, and later incorporated and developed in the later work. It is thus essential to an appreciation of Wittgenstein's conception of philosophy that one realize not only that he sees our philosophical perplexities as arising from certain forms of logical confusion, but that he sees us as deeply attached to our confusions, resistant to giving up the erroneous ways of looking at things upon which they rest.

It is important, however, that we realize that there are two aspects of the difficulty involved. There is what may be seen as a psychological resistance to see our urge for explanation as one of the traps of language that lead us into meaninglessness, and there is the natural difficulty, beyond our psychological resistance, of seeing our way through language. And so there are correspondingly two distinct tasks for philosophy. One is the task to guard against and uncover the powerful inclination 'to evade seeing the difficulties as the kinds of difficulties they are', which may show itself in our reluctance to see that we have transformed them into illusory problems, or that our propositions are simply nonsensical. The other is the task of facing the real difficulties we are inclined to evade - which certainly includes fighting our instinct to stay with the herd, as Wittgenstein puts it in obvious Nietzschean fashion - but it consists primarily in the kind of imaginative thinking required to give sense to our words, to be initiated in new forms of life or enter into a particular language game. It is a task that is inseparable from

(C) Blackwell Publishers Ltd. 2001 
that of learning to decipher what in us is seeking expression and what kind of expression is most appropriate and faithful to it; not just applying rules, but thinking them through. It is a process, as Diamond puts it, where 'the hearer's activity in understanding is close to the speaker's in constructing the sentence the hearer has in a sense to make the sentence his, but using the rules. The user of language - speaker or hearer - is a thinker of sense according to the rules' ${ }^{6}{ }^{67}$

Kremer's phrasing suggests also a second important feature in Wittgenstein's position. When he tells us that Wittgenstein wants us 'to change our relationship' to nonsense Kremer suggests, I think correctly, that Wittgenstein does not mean to do away with nonsense but to acknowledge its presence as an unavoidable aspect of our form of life in language, and to learn its place and significance within human experience. In fact, as Wittgenstein tells us in his 'Lecture on Ethics', it is the essence for example of ethical propositions that they are nonsensical, and although this means they do not add anything to our knowledge, that is no reason to dismiss them as unimportant. All to the contrary, they are a testimony of a human tendency that he holds in highest regard. This suggests, moreover, that we should not forget, as Diamond puts it, that 'sometimes the purposes with which we speak would not be served by sentences that make sense' ${ }^{68}$ There may be ways of relating to (and even of wanting) nonsense that are not erroneous, that is, uses of literally nonsensical language that nonetheless well serve specific needs. Although it may be right to hold back tears or an outburst of anger in some occasions, they may be perfectly adequate in others. That in his early work Wittgenstein's conception of philosophy is unable to make room for these uses of language points to one of the areas in his thought that will undergo substantial modification.

As Diamond observes, referring specifically to the ethical propositions of the Tractatus, once we have taken its lesson to heart, 'we shall not be inclined to describe the contrast [between empirical and transcendental uses of language] by appealing to notions like the limits of language, or the general form of a proposition; but we can nevertheless describe the ways in which we mark that contrast and the significance it has for us, if it still has significance for us' $^{\prime}{ }^{69}$ We must, therefore, learn to see philosophical discourse as aimed at bringing about a kind of self-understanding through one's own imaginative activity, teaching one to make 'certain distinctions in [one's] talk and thought and life, [trusting] that one has or can recognize that in oneself that would make those distinctions' ${ }^{70}$ Indeed one can see Wittgenstein's remarks on the Golden Bough as his first full-fledged exploration of the human impulse that underlies the many and varied uses of language that he will be able to recognize as legitimate ${ }^{71}$ after he has given up the limiting identification of meaningful language with the language of the natural sciences that he still espoused in the Tractatus. ${ }^{72}$

The kind of reflection made possible by the exercise of imagination in the Tractatus leads us to a different level in our understanding of language, where asserting is not separate from valuing, where thinking and desiring are part of the same act of language, where language use is not separate from issues of interest and attraction that become invisible from a purely logical perspective. I take the 
lesson of the New Reading to be that already in the Tractatus Wittgenstein is moving towards what I am inclined to call an 'aesthetics of speech', taking my cue here from Cavell who gives that name to the kind of studies that will be required when we take the idea of valuing 'as the other face of asserting', when we consider that

understanding what someone says is a function of understanding the intention expressed in his or her saying it, and [. . .] that one's intention is a function of what one wants, [so that] responding to what another says is to be seen as demanding a response to (the other's) desire. ${ }^{73}$

The consequent exercise of philosophical reflection will not therefore be intended to determine whether what is said is true or not, but 'why [one is inclined] to express it that way - or rather [...] to show that these questions are always together' ${ }^{74}$

\section{On Wrongly Inflecting Wittgenstein}

One of the reasons why Rorty's reading of Wittgenstein is initially so appealing is that he seems to correctly identify the movement of the later work towards what, following Cavell, we have called an aesthetics of speech. But there is here merely a superficial coincidence between Cavell and Rorty that hides a much greater and much more important divergence in philosophical purposes between them. So let us consider once more what we have learned from the New Reading.

In the Tractatus Wittgenstein is trying to do away with that theoretical perspective which takes the issue of the limits of language to be an epistemological problem about its foundations. For him it is the literalization of the picture of a transcendental place from which to fix the limits of language that erroneously leads us to assume that it needs an explanation, or requires a search for foundations. For Rorty, however, the Tractatus purports to resolve the problem but it does so in the wrong way, by taking the limits of language to be set by transcendental grounds, the showing of which in that book puts an end to the 'problems of philosophy'. (Thus the final pronouncement, 'Whereof we cannot speak, thereof we must remain silent' is read as a prohibition). According to his view, it is the advance of the later work that it rejects the mysticism of the Tractatus, and shows instead that the limits of language are not determined by metaphysical foundations, but by the actual 'conversation of mankind'; so the later philosophy gives the 'problem' a pragmatist solution. This is the way Rorty words his thought:

The Tractatus had said: there can be no genuine discursive discipline which deals with those matters called 'the problems of philosophy' for here are the limits of language, and thus of discursive inquiry. The Philosophical Investigations said: there can be as much of a discipline as you care to develop, but do you really wish to do so? ${ }^{75}$

(C) Blackwell Publishers Ltd. 2001 
It becomes clear that both the 'mystical' reading of the Tractatus, which Rorty is presupposing, as much as his interpretation of the later philosophy share the same assumption that what is at issue is the determination of a criterion of meaning and nonsense. The only difference is that whereas the mystical reading of the Tractatus placed it in the transcendental structures of reality, Rorty places it in the conventional agreements of the community. But the New Reading shows that, even in the Tractatus, Wittgenstein rejects the idea that we can establish such criteria prior to the actual uses of language as the misunderstanding of logic that is responsible for the illusory problems of philosophy. The significance of the 'philosophical problem' of the limits of language is for Wittgenstein, obviously then, not epistemological (it is not even propositional), but rather ethical, insofar as it manifests a kind of spiritual hybris that disconnects man from what gives meaning to his life. ${ }^{76}$ To take it as an epistemological problem is to wrongly inflect Wittgenstein. It involves the very categorical mistake against which he is attempting to instruct us.

For Wittgenstein the philosophical exercise then becomes an exploration into our own nature as it is reflected in the grammar of our language; it means learning to live with its pictures, not taking them literally and thus falling into confusion, but also not dismissing them as mere superstitions. In one sense what the Tractatus is on its way to teaching us is, as Timothy Gould says about Cavell's understanding of Wittgenstein, to internalize the desires and fantasies that underlie our philosophical problems in order to undo our mechanisms of defense against the work they require. For Rorty however, everything remains at the level of conceptual confusion, so that his thinking, as Gould has pointedly remarked, seems to obey an explicit wish to do away with them, seeing them as 'merely a series of professional habits' ${ }^{77}$ It manifests, in other words, the very impetus that refuses to acknowledge a level of human subjectivity that is beyond the control of will or reason. ${ }^{78}$ But there is in Wittgenstein a recognition of something much deeper than what we can anticipate through our own notions. ${ }^{79}$ Rorty's picture of Wittgenstein is totally opposed to the spirit that animates the later philosophy, being derived as it is, from a conception of the world in which - as Rorty describes it incessantly in his writings - everything is reduced to pragmatic calculations, utilitarian deliberations, and arbitrary decisions: that is, to a contingency whose spiritual poverty - rather than lamented - is praised as a virtue. ${ }^{80}$

It seems clear to me, as I have already said, that from the beginning Wittgenstein sharply distinguished the erroneous attempt to explain language that results in nonsense, from the inclination which that nonsense reveals. The Tractatus is able to deflate by its exercise the attempts at explanation by showing the futility of our project to 'draw the limits of language'. But it does not do away with the impulse behind it, nor do I believe it is meant to. As Diamond writes:

There is an important resemblance between ethical sentences and philosophical ones, seen imaginatively as apparently making sense: both ethical and philosophical nonsense reflect the attractiveness of the idea of a point of view on the world as a whole, whatever may happen in it. But I 
think that if we read the Tractatus right, the upshot of the book will be different in regard to the two sorts of utterers of nonsense. The attractiveness of philosophical sentences will disappear through the kind of self-understanding that the book aims to lead to in philosophers; the attractiveness of ethical sentences will not. ${ }^{81}$

The resemblance between ethical and theoretical propositions resides in the common need they give expression to which is found, as Diamond rightly identifies it, in the picture - itself embedded in the grammar of our language - of our contemplating the world as a totality; what is manifested in the assymetry, however, is the distinction between the explanatory urge enacted in the theoretical propositions, their intention to explain, which is dissolved by the demonstration of the Tractatus, and what I am calling the need for transcendence, the inclination to 'run against the limits of language', which is not. Only in the theoretical propositions of philosophy does this natural picture become an illusion, only there does it breed an explanatory urge and thus make us its captive. The Tractatus shows that the picture is theoretically an illusion; but it is Wittgenstein's considered view, I believe, as he articulates it in his 'Lecture on Ethics', that the impulse itself and the image of confronting the world as a totality, while leading to what are theoretically nonsensical statements in Ethics, 'in so far as it springs from the desire to say something' about the ultimate meaning of life, the absolute good, the absolutely valuable, etc., gives voice to a human tendency that is of the highest importance. It points to a task the importance of which, although impossible to discern from the standpoint of his philosophy at the time, he cannot dismiss. ${ }^{82}$

The elucidatory propositions of the Tractatus make us see the illusoriness of the belief that there is something to explain, and hence allow us to recognize the longing behind our propositions without falling into the illusion that they foster. Shifting the context of our consideration by appealing to our imaginative understanding, Wittgenstein allows us to consider the picture of the world as a totality, or of our standing outside logic, in a deeper way, more attuned to what is moving behind it than to the theoretical perspective that seeks to reduce it and do away with it.

Although in its view of meaningful language as the language of the natural sciences it is impossible to accept the linguistic uses that result from that longing as legitimate, so that they can only be seen as attempts to say the Unsayable, in its appeal to the imagination the Tractatus allows us to attend to what is active in our inclination towards nonsense - in our 'urge to run against the limits of language' - , and to see that what is shown by its propositions is not something 'beyond language'; it is not even a something, although the picture in which we tend to imagine it suggests that much. Giorgio Agamben puts it this way:

The decisive experience, which it is said is so difficult to explain for those who have lived it, is not even an experience. It is nothing but the point at which we touch the limits of language. But what we touch at that

(C) Blackwell Publishers Ltd. 2001 
moment is obviously not a thing, so new and awesome that we lack the words to describe it: it is, rather, matter. . .He who touches [. . .] his own matter, simply finds the words to speak. Where language stops begins not the Unsayable, but the matter of speech. ${ }^{83}$

'Beyond the limits of language' does not refer to some unknowable realm, but to the point where we encounter that dense opaque matter that our emotions and our bodily impulses are to thought before they are articulated in words, before they are 'lifted' into language. ${ }^{84}$ Although from a literal perspective it marks a limit in our capacity to express ourselves 'meaningfully', it is in another sense also an opening to the unbounded possibilities of meaning that still await their realization in language; it is the place of imagination from which our words must be forged.

Beyond the justificatory urge dissipated by the work of the Tractatus, I want to say, there still remains its Ethical intuition. When instead of literalizing its picture of our standing outside language, we attend to what is active in our sense of its limits' we speak from a different place than when we speak simply from the concepts with which we describe the world, or the things we do in it, or the things we think about it. But in the Tractatus there is yet no home for that intuition. Diamond has pointed out that 'as Wittgenstein saw traditional philosophical activity, it would not survive recognition that the intentions in it were incompatible with making sense', ${ }^{85}$ but this resort to the imagination teaches us to speak from another place in addressing our philosophical perplexities than from the empirical or theoretical level at which we address our scientific problems.

If we can speak at all of 'progress' in philosophy, then it may be seen in our ability to address that fateful longing for the transcendent without falling into its illusion. We must learn to see it not as referring us to something we cannot do or reach, as something that we cannot have and must renounce but to the very task of thought as an activity that begins and ends with the concrete instances of our life in all their obscurity and complexity. The purpose of the clarification of logic in the Tractatus as is described by the New Reading, or the search for grammatical perspicuity of the later work, does not respond then to the attempt to provide epistemological foundations to language but to the need to overcome the source of the illusion that leads us to want to argue for or against them and so distracts us from the real task of living, and the real perplexities to which the philosophical calling is a response. ${ }^{86}$

Victor J. Krebs

Departmento de Filosofía

Universidad Simón Bolívar

Apartado Postal 89000

Sartenejas - Baruta

Estado Miranda

Caracas 1080, Venezuela

vkrebs@usb.ve,vjkrebs@cantv.net

(C) Blackwell Publishers Ltd. 2001 


\section{NOTES}

1 Rorty 1982: 20.

2 Cavell 1989: 30.

3 Cavell 1989: 31-32, my italics.

4 Rorty 1989: 21.

5 Wittgenstein 1993: 44.

6 Rorty 1982: xlii.

7 It is precisely the inability to recognize in our uses of language that same ritualistic or expressive dimension that Wittgenstein finds in the ritual practices in Frazer, which constitutes the constant underlying concern in his later work; and it is that very blindness that manifests the generalized spiritual poverty that leads him to imagine our culture as a site of destruction: 'I once said, perhaps rightly', he writes in his journals, 'the earlier culture will become a heap of rubble and finally a heap of ashes...' (Wittgenstein 1980: 3).

8 Wittgenstein 1980: 56.

9 Wittgenstein 1980: 50.

10 Diamond 1991: 88.

11 Wittgenstein 1953: §108.

12 I have chosen in this paper to set up my account of the New Reading of the Tractatus in terms of the contrast between Rorty and Cavell because it is, to my mind, precisely analogous to the difference which separates it from the Received Interpretation. But we could profitably compare in the same way, for example, the understanding of Wittgenstein articulated in the work of James Conant with that of D. Z. Phillips (particularly in his latest book, Phillips 1999).

13 Cora Diamond and James Conant started developing their reading in the mid-eighties. Thus, Diamond 1988, Conant 1989 and 1991, were written at the end of the decade, and were followed by Diamond 1991, and Conant 1993.

14 Floyd 1995, 1998, 2000a, 2000b.

15 Ricketts 1996.

16 Goldfarb 1997.

17 Kremer 2001.

18 There are differences of inflection and emphasis, and in some cases even small differences of interpretation that suggest it is a family of readings rather than a single reading that is being developed. I will make allusion to these differences when necessary in the text that follows, but for obvious expository reasons I am neglecting them at this stage.

19 Although it has not featured prominently in the expositions of its main representatives, it is clear that the question of the ethical point of the Tractatus constitutes one of the important motivations behind their efforts. Diamond 1991 emphasizes the importance of the 'transcendental' nature of his ethical position in the Tractatus for a correct understanding of the attitudinal difference between Wittgenstein's ethos throughout his life and that which characterizes most interpretations of the later work. Conant develops his interpretation of the Tractatus in close parallel with issues in Kierkegaard's pseudonymous work, Concluding Unscientific Postscript, and suggests at various points (Conant 1989, 1991, 1993) that the underlying concern in Wittgenstein's early and later work is akin to what Kierkegaard called 'the monstrous illusion'. The ethical inflection of his interpretation of Wittgenstein becomes most clear in his exchanges with D. Z. Phillips (Conant 1993; Phillips 1999), who defends a conception of philosophy in the later work that is completely opposed to the spirit that characterizes Conant's interpretation. Juliet Floyd (1998, 2000a,

(c) Blackwell Publishers Ltd. 2001 
2000b), while working primarily on the philosophy of mathematics, identifies a strand of Wittgenstein's ethical concern in his discussions around the source of conviction [Triftiger Grund] for proofs, and in his critique of the conception of logic as an organon of philosophy. And most recently, Michael Kremer has addressed this issue directly in a suggestive way, in light of theological considerations on justification and faith, arguing that Wittgenstein's ethical point in the Tractatus is 'to relieve us of [the] need for ultimate justification [... as] thinly disguised manifestations of the will to power, the will to place oneself at the center of the universe' (Kremer 2001: 51). As should become clear in what follows I agree with that assessment.

20 Especially in light of its partiality to the logical sections and its tendency to separate and give them primacy over its ethical pronouncements, dismissing the latter as mere idiosyncratic afterthoughts tangential to its main thrust. Peter Hacker, for instance, wrote in 1979: 'the primary inspiration of the so-called 'mystical' sections of the Tractatus lies outside the book. To be sure, some aspects of the transcendental theses dovetail into the conception of meaning with the added advantage of emerging from this union as inexpressible. This does not, of course, imply any belittling of the significance of these doctrines for Wittgenstein. On the contrary, the fact that the two strands of thought could be interwoven thus may well have struck Wittgenstein as partial confirmation of each. For there is no doubt that when he compiled the Tractatus, it was the very fact that the philosophy of logic which he propounded drew the limits of language at the boundary of all that is 'higher' - ethics, aesthetics, and religion, as well as philosophy itself and the attendant doctrines of transcendental solipsism - which seemed the main achievement of the book.' (Hacker 1979: 105). Hacker, following the positivist lead, clearly distinguishes two separate and mutually independent strands of thought in the text - that which is concerned with linguistic meaning, and what he calls the 'mystical' sections - and sees their overlapping as a happy coincidence instead of as sign of any overarching unity.

21 Engelmann 1968: 143.

22 Diamond 1991: 89-90.

23 Anscombe 1971: 12.

24 Conant 2001: 380. (Although Conant goes on to identify the issues here with the question regarding the meaning of the terms 'elucidation' and 'nonsense', the substance of his claim refers directly to the ethical import of Wittgenstein's reaction to Frege).

25 Not a text of ethics, which would be something entirely different, suggesting that Wittgenstein was attempting to offer views about the issues that belong to a specialized field - something which would be exactly opposed to the spirit of his thought.

26 This is what I take to be the upshot of Conant's reflections (in Conant forthcoming) specifically with regard to the way in which he argues Wittgenstein carries Frege's own admissions about the procedure of elucidations to their whole term.

27 Wittgenstein 1922: Preface, p. 27.

28 Wittgenstein 1993d: §87, p. 165 [slightly amended translation].

29 Cf., Diamond 1988: 185.

30 Wittgenstein 1993c: 119.

31 Diamond and Conant distinguish between the frame remarks and the actual theoretical body of the Tractatus, and although this is a helpful distinction to get a sense of the two main levels at which the text works, it still needs to be carefully worked out. Conant has qualified Diamond's (and his own initial) spatial characterization of the frame remarks (as those found in the Preface and in the concluding sections) by noting that it is not their location but the role they play within the elucidatory aim of the work that determines whether they form part of the frame or not (Conant 2001: 457, fn 135). So remarks like 
3.32-3.326, 4.111-4.112, found in the body of the text may be seen as frame remarks despite their place of occurrence since they are imparting 'instructions concerning the elucidatory aim and method of the work'. But even on the basis of this characterization, there is disagreement. Kremer, for instance, takes 6.54 (about 'the strictly correct method') to be nonsensical, and hence not a frame remark, whereas Conant includes it amongst his examples of frame remarks. But there are other remarks, such as for instance 5.4733, where Wittgenstein comments on Frege's conception of sense that would seem to constitute part of the criticism of attempts to provide theoretical means to draw the limits of language, and so cannot be nonsensical. (The same is the case, I think, with the propositions of arithmetic, for instance). But then these would constitute a category different as much from that of 'frame' remarks or that of 'nonsensical propositions'. Juliet Floyd goes so far as to argue (in the conclusion to Floyd 2000b), that there is no clear distinction to be drawn between the frame of the Tractatus and what is inside the frame since the notion of nonsense in the Tractatus corresponds to no generic grammatical category, and that this fact punctuates the insight that Wittgenstein is applying in the book that 'there is no way for philosophy to achieve a perspective from which to systematically chart the bounds of sense'. In any case, these complications in the textual structure of the Tractatus may very well be intrinsic to its particular expository method, and so a reason to agree with Conant's suggestion (Conant 1989) that in the later work Wittgenstein had to develop a writing style that was more adequate to his purposes.

32 The propositions of the Tractatus are meant to be 'dialectical way stations' (Conant 2001: 377) towards recognizing the illusion upon which both the positivist and the mystical readings rest. The misunderstanding is that we have been able, through the propositions of the Tractatus, to define the conditions for sense, that we have indeed managed to provide a criterion that distinguishes nonsensical propositions from meaningful ones. But it is precisely the assumption that we can settle the issue at the level of theory and logical formalization, that Wittgenstein is attempting to show is impossible.

33 Conant 2001: 422.

34 Floyd 1998: 82.

35 Floyd 1998: 87 - my italics.

36 Floyd 2000a: 13.

37 Wittgenstein 1922: 6.54 (I have slightly modified Conant's translation of this passage).

38 Cf. Diamond 1988: 195.

39 Hacker 2000: 359-60.

40 McGinn 1999: 496.

41 Moore 1959: 304-5.

42 That we may later, with hindsight, articulate the experience as a thought, so that we may be able to accept the truth which Wittgenstein is offering along the way of this demonstration, does not contradict this claim. If this is the theoretical lesson of the book, it is not aimed at the (now ostensibly impossible) task of drawing limits to thinking, and, furthermore, it rests not on argument but on the practical exercise of the book, which therefore works in a dimension different from that of assertion.

43 Diamond 1991: 57

44 Even though we might be inclined to articulate our discovery in terms of a theoretical position after we have grasped the situation. So that we should see what is going on here not as a rejection of all theorizing but as a definition of the limits of theorization, an attempt to clearly spell out the temptation to which any theoretical project may succumb and to diagnose its illusory nature.

(C) Blackwell Publishers Ltd. 2001 
45 Cf. 'first I grasp that there is something which must be; then I see that it cannot be said; then I grasp that if it can't be said it can't be thought (that the limits of language are the limits of thought); and then, finally, when I reach the top of the ladder, I grasp that there has been no 'it' in my grasp all along (that that which I cannot think I cannot 'grasp' either)' (Conant 2001: 46).

46 Floyd 2000a: 243.

47 As Conant puts it: 'our inclination to believe that we can perceive the symbol in the sign, when no method of symbolizing has yet been conferred on it, is not one that is to be extirpated, at a single stroke, by persuading the reader of some 'theory' of meaning. As is made clear in $\S 6.53$, the aim is to demonstrate to the metaphysically-inclined speaker that he has given 'no meaning to certain signs in his sentences' on a case by case basis' (Conant 2001: 46.

48 Logical formalization, Wittgenstein insists in his mathematical discussions, is unable to account for what gives the proofs their conviction, their forcible ground [Triftiger Grund], so we cannot take the project of formalization as an adequate philosophical tool. As Floyd writes, Wittgenstein felt the temptation to use this new tool as an organon for the development of theories of language, mind and knowledge was [...] riddled with confusion and bound to obfuscate both the new contribution of the new logic and the nature of philosophy' (Floyd 2000a: 234-5). Wittgenstein is trying to uncover the confusion behind the belief that logic could constitute a philosophical organon, capable of accounting for our intuitive notion of meaning, and hence for addressing our philosophical concerns about meaning and understanding.

49 Cf: 'To the clear sighted it is obvious that a proposition like 'the watch is lying on the table' contains a lot of indefiniteness, in spite of its form's being completely clear and simple in outward appearance. So we see that this simplicity is only constructed [. . .] It is thus also clear to the UNCAPTIVE spirit that the sense of the Satz 'the watch is lying on the table' is more complicated than the Satz itself' (Wittgenstein 1979: 21.6.15-112.6.15). And further: '4.9.14. If logic can be completed without answering certain questions, then it must be completed without answering them./ / 20.9.14. That a sentence is a logical picturing of its meaning [Bedeutung] is obvious to the uncaptive eye.' Wittgenstein is appealing in these two notes from his Notebooks 1914-16, as Frege admits to having to do too (see Conant forthcoming), to our ordinary sense of language, and thus making the first step towards the shift in the subject of philosophy that his elucidations are achieving. In this sense we can see that this shift involves precisely the delimitation of the ethical sphere from the inside, as Wittgenstein told von Ficker was the objective of the Tractatus, for that about which we must remain silent is precisely what is clear to anyone with a clear sight, someone that is not trapped in the illusion that logic could determine by itself, independently of the context of use (cf. 3.326). When Kremer writes, for instance, that 'logic itself is "beyond grounds". It is neither a source of justification nor something to be justified. It is not a theory or principle, but an ability which pervades both our thinking and our acting, our taking-true and making-true, without serving as "ground" for either', I believe one can read him as moving in this direction (Kremer 2001: 70).

50 Ricketts 1996: 94.

51 Diamond 1991: 68.

52 Cf. 'How can we not know that we are not informing ourselves of something when we think we are? Here one might capture a sense of how the problems of philosophy become questions of self-knowledge' (Cavell 1979: 240).

53 We can see then the irony intended in Wittgenstein's claim at the beginning of the Preface of the Tractatus when he writes that 'this book will perhaps only be understood by 
those who have themselves already thought the thoughts which are expressed in it - or similar thoughts', for it does depend for its teaching on our having thought for ourselves these same [empty] thoughts Wittgenstein has thought. It is for this reason that the book is immediately said not to be a text book, but one whose object 'would be attained if it afforded pleasure to one who read it with understanding'. But its pleasure is not a merely aesthetic pleasure, as Frege objected to Wittgenstein in a spirited letter: 'What you write me about the purpose of your book is strange to me. According to you, that purpose can only be achieved if the other has already thought the thoughts expressed in it. The pleasure of reading your book can therefore in no way arise through the already known content, but rather, only through the form, in which is revealed something of the individuality of the author. Thereby the book becomes an artistic rather than a scientific achievement; that which is said therein takes a back seat to how it is said. I proceeded in my remarks from the assumption that you wanted to communicate a new content. And then the greatest clarity would indeed be the greatest beauty.' (Bad Kleinen, 16.Sept. 1919, in Gottlob Frege: Letters to Ludwig Wittgenstein, English translation by Burton Dreben and Juliet Floyd [unpublished]). It is true that the purpose of the book is not achieved by the content of the thoughts it expresses, but not because they are already known and so the only discovery is a different way in which they are expressed, but because what is common is something completely new to both, namely the discovery that these thoughts are empty thoughts, that there is an activity of language, that of hovering over well-formed sentences (possible propositions) without really knowing how to fix the meaning of its constituents, that tells us something not about the propositions but about ourselves. The pleasure Wittgenstein speaks about then is not pleasure for the style of his writing, but for the dispelling of self-illusion that it affords. So it is not true that Wittgenstein expects the reader to derive pleasure from 'a revelation of the individuality of the author', for he is implicitly suggesting that in sharing these peculiar thoughts one does not learn something about the author, namely his style, but recognizes oneself in the work, in the apparent meaningfulness of its propositions! It is indeed not a scientific achievement in one sense, for it provides no propositional content as its product; but it is not either merely an artistic achievement, for it does contribute to our understanding, it provides the kind of enlightenment that releases us from error and opens space for truth - as Wittgenstein puts it himself. And this achievement is in that sense a prerequisite for the scientific. It is Frege's initial assumption that is mistaken; what is questioned by the text is precisely that there is any content to what is being communicated, so the greatest clarity is indeed what gives the greatest pleasure, but precisely not, as Frege concluded it should be, because it illuminates its meaningful content but because it dispels its illusory meaning. In other words, not because it affords us the truth but because it does away with error.

54 Conant 1991b: 158.

55 They do not 'modify a proposition or a belief'; they are not, in other words, aimed at either asserting or denying the truth of propositions (Floyd 2000a: 252).

${ }^{56}$ The insight the Tractatus yields is not in the form of a propositional truth, whether effable or ineffable, and it is not merely about the logic of propositions. As Diamond puts it: 'a proposition's being an elucidation is a matter of the context of use, not of the content. I may teach you the meaning of a word by using it in a sentence; that the sentence serves as an elucidation has nothing to do with its internal features' (Diamond 1991: 70, note 9). In other words, the genuine insight that Wittgenstein provides us has to do with the external features of the proposition (with our relation to propositions, which belongs to the realm of imagination), not its internal logical features alone (not with their propositional content and so not in the dimension of assertion). 
57 Conant 2001: 423-4.

58 The Tractatus shows the insufficiency of the theoretical attempts to demarcate the conditions of sense, their superfluity, by making it evident that the logic of language is in order as it is, so much so that the ultimate appeal of the exercise of the book which overrides the theory it purports to expound, is to our practical linguistic sense; it thus also shows its impossibility, by showing that logic is internal to language, that we cannot stand outside of language, by demonstrating that 'the limit can only be drawn in language'.

59 This is in fact also the moral which we can draw, according to Floyd, from his discussions on mathematics: 'One moral to draw from Wittgenstein's discussions of mathematics is that this sort of philosophy calls for one to go to a very great distance in trying to understand what moves a person attempting to do something which by the person's own lights is not perspicuous. Wittgenstein's philosophy is devoted, in large measure, to inculcating in his readers, through a dialectical form of writing, an appreciation of the reality, the centrality, and the difficulty of bringing about such understanding in philosophy' (Floyd 2000a: 255). The shift in the focus in philosophy that is signalled here involves its centering on issues of ethical consequence, linking as it does logical questions with the problem of self-deception.

60 Wittgenstein 1953: §341.

61 Wittgenstein 1993d: 185.

62 Wittgenstein 1980: 65.

63 Conant forthcoming.

64 Conant forthcoming. In other words, it is an essential requirement that we see, not only that we cannot solve them theoretically, but that in attempting to we lose sight of what the real problems, and thus our real needs, really are, confusing the nature of the philosophical perplexity and turning it into a scientific problem. Marie McGinn is therefore pointing to the same phenomenon Wittgenstein is concerned with in the Tractatus when she explains that for the author of the Investigations, "[w] hat we are concerned with when we ask questions of the form "What is time?", "What is meaning?", "What is thought?" is the nature of the phenomena which constitute our world. [. . .] in asking these questions, we are tempted to adopt an attitude towards these phenomena which, Wittgenstein believes, makes us approach them in the wrong way, in a way which assumes that we have to uncover or explain something.' (McGinn 1997: 18). Instead of responding appropriately to the transcendental perplexity that moves him, to the impulse 'to run against the limits of language', the philosopher confuses himself trying to explain, uncover, or resolve problems that do not answer his true need. Instead they rather obey the perverse logic of words that have already been disconnected from their real ground by an attitude of detachment - objective, theoretical and explanatory - that we find ourselves inclined to adopt, that turns our own words into forms of expression that prevent us in all sorts of ways from seeing that it is a matter of everyday things [dass es mit gewöhnlichen Dingen zugeht], by sending us in pursuit of chimaeras' (Wittgenstein 1953: §94).

65 Kremer 2001: 57.

66 Wittgenstein 1993d: 161.

67 Diamond 1996: 111.

68 Diamond 1991: 78.

69 Diamond 1991: 88.

70 Cf. Diamond 1991: 89.

71 Conant believes that in the Tractatus Wittgenstein was not so blind as not to recognize other uses of language than non-constative uses. He did not even reduce them to elucidations alone. What he did not do is recognize them as legitimate uses [Gebrauch] of 
language; and this means indeed that he was still, perhaps for merely metholodogical reasons, wedded to an overly narrow conception of language and of philosophy, which in the end was in conflict with his insight that the belief in the possibility of drawing limits to language was the result of philosophical illusion (see Conant 2001 429, note 26).

72 I agree, therefore, with Hilary Putnam, when he writes that the idea that what can be expressed in language equals what can be expressed in scientific language [. . .] seems to me the target of much of Wittgenstein's later work. Wittgenstein eventually really freed himself from the Tractarian picture of language as picturing facts [. . . In my view it was one thing for Wittgenstein to realize that that picture explodes upon itself, and quite another thing [...] to find a different way of looking at language. In the end he also (rightly) rejected the idea that there is any one function that all language which is susceptible of truth and falsity, of rational discussion, of justification and objectivity, etc. must subserve. And I find this identification of meaningful language with propositions of natural science in tension with the rejection of the idea of limits of language. ...' (Putnam 1998: 111). What this means is that the Tractatus had not fully managed to free itself from the bewitchment of the picture of limits of language, that it had to come to recognize that its own restriction of legitimate uses of language was still a sign of the attempt to draw the limits of meaning. This limitation may be seen as registered correspondingly in the ethical purpose of the book, as the residual hybris that may be detected in Wittgenstein's seeing himself 'as having constructed one ladder which he could climb and discard once and for all, which could solve all the problems of philosophy - so that he could then abandon his philosophical vocation and take up a career of service as a village school teacher', as Kremer says. I agree with him that 'Wittgenstein's return to philosophy was occasioned by his realization that "the edifice of [his] pride" had still to be "dismantled"', and see this as marked in the recognition that significant uses of language cannot be determined in advance, and 'in his coming to accept his inability to achieve a simple and neat resolution of all philosophical difficulties at one fell swoop' (Kremer 2001: 69, note 22).

73 Cavell 1979: 94.

74 Cavell 1979: 95.

75 Rorty 1982: 20.

76 The picture of a position outside language creates the illusion that we can determine the limits of language prior to its use, and thus disconects us from the concrete contexts where our words acquire meaning, where they become authentic means of self-expression. So the logical and the ethical problems are intimately connected for Wittgenstein, and in disabusing us of the illusion of a perspective sub specie aeterni he is indeed, as Kremer puts it, 'also freeing us to live in the world, rather than detaching ourselves from it' (Kremer 2001: 60).

77 Gould 1998: 17.

78 This move has more dramatic consequences in what, on the basis of the New Reading of the Tractatus and following Cavell's diagnosis of the later work, I take to be a central concern of Wittgenstein's philosophy, namely, that resistance to the intimacy of our words with the world called skepticism, and more generally the skeptical impulse to repress or deny the dimension of affect and desire in our experience and language. It allows Rorty in the end, as Gould so sharply puts it, 'at a stroke' to cut off 'the skeptical strand of the empiricist from the entire range of questions concerning the Romantic anxiety about using language to reach the thing itself' (Gould 1998: 18), and thus to make philosophy blind to an essential aspect of its calling, which is, in one formulation of it, the need for transcendence.

79 This, it seems to me, is what Frege is acknowledging when he tells us that he is forced or compelled to express himself in an infelicitous manner: [that] he is attempting to struggle against "an imprecision forced on us by the nature of language", one which

(C) Blackwell Publishers Ltd. 2001 
"compels" him "to use an inappropriate expression which obscures - falsifies - the thought." ' (Conant forthcoming). If we consider that, as Conant argues, it is this honesty and this recognition on Frege's part that constitutes the reason why Wittgenstein valued his philosophical work, then we can see the great distance that separates the kind of philosophy (and the conception of the human subject, the play of forces that underlie the philosophical effort) exemplified by Frege and Wittgenstein, from what is ascribed to him by someone like Rorty, who claims that the problems of philosophy are the result of stupid mistakes, and that what Wittgenstein wants is to free us to see the world as something that is subject to our will and reason.

80 Nevertheless, Rorty's picture of later Wittgenstein held sway, in one way or another, for well over a decade in America, although the situation has been rapidly changing in the nineties. It is worth mentioning the following books as representatives of a new spirit in the reception of Wittgenstein's work: Cavell 1989; Monk 1990; Mulhall 1990; Johnston 1993; Sass 1994; Stern 1995; McGinn 1997; Bearn 1997; Eldridge 1997.

81 Diamond 1991: 74.

82 Wittgenstein 1993a: 44. In other words, the 'problems of philosophy' are illusory for Wittgenstein, but not the awe that underlies our philosophical perplexities, even if it may disappear or seem insignificant once we have transformed these into scientific problems in need of intellectual solution - just as the experience Wittgenstein asks us to imagine of someone suddenly growing a lion's head and beginning to roar, would cease to be miraculous once we attempted to vivisect the man in order to see what had caused the aweful transformation (Wittgenstein 1993a: 43).

83 Agamben 1995: 37. The final sentence of this passage suggests, in an appropriately metaphoric way, that the liberating vision here is one that comes from the work of imagination: 'Those who have not reached as in a dream, this woody substance of language, which the ancients called silva (wildwood), are prisoners of representation, even if they keep silent.' (Ibid., idem, my underlinings)

84 I have described in an initial way the relation between language and the bodily that I see in Wittgenstein's view in Krebs 2000.

85 Diamond 1991: 75.

86 I wish to express my gratitude to Juliet Floyd, whose splendid dialogue has been invaluable for my work on the New Reading, and to Jim Conant, whose generous correspondence has been a source of inspiration to me. I have enormously benefited from their lucid work, and their kindness. I am also grateful to Michael Kremer and to Bill Day, for their insightful comments on different versions of this text, and to the audience at Vanderbilt University, where it was read in April 2000, for their stimulating discussion. Finally, I thank the Philosophy Department at Boston University for the resources it made available to me as a Visiting Research Scholar during my sabbatical year, 1999-2000, at which time the present paper was written.

\section{REFERENCES}

Agamben, G. (1995), Idea of Prose, Albany: SUNY Press.

Anscombe, G. E. M. (1971), An Introduction to Wittgenstein's Tractatus, Philadelphia: University of Pennsylvania Press.

Bearn, G. F. (1997), Walking to Wonder: Wittgenstein's Existential Investigations, Albany: SUNY Press. 
Cavell. S. (1979), The Claim of Reason: Wittgenstein, Skepticism, Morality and Tragedy. New York: Oxford University Press, 1979.

Cavell. S. (1989), This New Yet Unapproachable America: Essays After Emerson After Wittgenstein. Albuquerque: Living Batch Press.

Conant, J. (1989), 'Must We Show What We Cannot Say?', in: The Senses of Stanley Cavell, Fleming, R. \& Payne, M. (eds.), Lewisburg: Bucknell University Press.

Conant, J. (1991a) 'Throwing Away the Top of the Ladder' in Yale Review, vol 79, no. 3.

Conant, J. (1991b) 'The Search for Logically Alien Thought: Descartes, Kant, Frege, and the Tractatus', in: Philosophical Topics, vol. 20, no. 1.

Conant, J. (1993) 'Kierkegaard, Wittgenstein and Nonsense', in Pursuits of Reason: Essays in Honor of Stanley Cavell, Ted Cohen, Paul Guyer and Hilary Putnam (eds.), Lubbock, Tx: Texas Tech University Press.

Conant, J. (2001a), 'The Method of the Tractatus', in: From Frege to Wittgenstein: Perspectives on Early Analytic Philosophy, Erich H. Reck (ed.), Oxford: Oxford University Press.

Conant, J. (forthcoming), 'On Going the Bloody Hard Way in Philosophy' in: Possibilities of Sense, John Whittaker (ed.), New York: Macmillan.

Diamond, C. (1988), 'Throwing Away the Ladder: How to Read the Tractatus', in Philosophy, 63.

Diamond, C. (1991), 'Ethics, Imagination, and the Method of the Tractatus', in: Bilder der Philosophie, Heinrich, R. and Vetter, H. (eds.), Vienna: Oldenbourg.

Diamond, C. (1996) 'What Nonsense Might Be', in The Realistic Spirit: Wittgenstein, Philosophy, and the Mind, Cambridge: The MIT Press.

Eldridge, R. (1997), Leading a Human Life: Wittgenstein, Intentionality and Romanticism, Chicago: University of Chicago Press.

Engelmann, P. (1968), Letters from Ludwig Wittgenstein. With a Memoir, New York: Horizon Press.

Floyd, J. (1995), ‘On Saying What You Really Want to Say: Wittgenstein, Gödel, and the Trisection of the Angle', in Jaako Hintikka (ed.), From Dedekind to Gödel: The Foundations of Mathematics in the Early Twentieth Century, Dordrecht: Kluwer Academic Publishers.

Floyd, J. (1998) 'The Uncaptive Eye: Solipsism in Wittgenstein's Tractatus', in Loneliness, Leroy S. Rouner (ed.), Notre Dame: University of Notre Dame Press.

Floyd, J., (2000a) 'Wittgenstein, Mathematics, and Philosophy', in A. Crary \& R. Read (eds.), The New Wittgenstein, London: Routledge.

Floyd, J. (2000b), 'Number and Ascriptions of Number in the Tractatus', in Floyd, J., and Shieh, S., (eds.), The Analytic Tradition in Twentieth Century Philosophy, Oxford: Oxford University Press.

Goldfarb, W. (1997), 'Metaphysics and Nonsense: On Cora Diamond's The Realistic Spirit', Journal of Philosophical Research, 22.

Gould, T. (1998), Hearing Things: Voice and Method in the Writings of Stanley Cavell, Chicago: University of Chicago Press.

Hacker, P. M. S. (1979), Insight and Illusion: Themes in the Philosophy of Wittgenstein, reprinted Bristol: Thoemmes Press (1997).

Hacker, P. M. S., (2000), 'Was He Trying to Whistle It?', in A. Crary \& R. Read (eds.), The New Wittgenstein, London: Routledge.

Johnston, P. (1993), Wittgenstein: Rethinking the Inner, London: Routledge.

Krebs, V. J. (2000), 'The Subtle Body of Language and the Lost Sense of Philosophy', Philosophical Investigations, 23: 2.

Kremer, M. (2001), 'The Purpose of Tractarian Nonsense', in Noûs, 35.

McGinn, M. (1997), Wittgenstein and the Philosophical Investigations, London: Routledge.

(C) Blackwell Publishers Ltd. 2001 
McGinn, M. (1999), 'Between Metaphysics and Nonsense: Elucidations in Wittgenstein's Tractatus', in The Philosophical Quarterly.

Monk, R. (1990), Ludwig Wittgenstein: The Duty of Genuis, London: Cape.

Moore, G. E. (1959), Philosophical Papers, London: Allen and Unwin.

Mulhall, S. (1990), On Being in the World: Wittgenstein and Heidegger on Seeing Aspects, London: Routledge.

Phillips, D. Z. (1999), Philosophy's Cool Place, Ithaca: Cornell University Press.

Putnam, H., (1998), 'Floyd, Wittgenstein, and Loneliness', Loneliness, Leroy S. Rouner (ed.), Notre Dame: University of Notre Dame Press.

Ricketts, T. (1996), 'Pictures, Logic, and the Limits of Sense in Wittgenstein's Tractatus', in H. Sluga and D. Stern (eds.), The Cambridge Companion to Wittgenstein, Cambridge: Cambridge University Press.

Rorty R. (1982), 'Keeping Philosophy Pure', in Consequences of Pragmatism, Minneapolis: University of Minnesota Press.

Rorty R. (1989), Contingency, Irony and Solidarity, Cambridge: Cambridge University Press.

Sass, L. R. (1994), The Paradoxes of Delusion: Wittgenstein, Schreber, and the Schizophrenic Mind, Cornell: Cornell University Press.

Stern, D. G. (1995), Wittgenstein on Mind and Language, Oxford: Oxford University Press.

Wittgenstein, L. (1922) Tractatus Logico Philosophicus, C. K. Ogden (transl), London: Routledge \& Kegan Paul.

Wittgenstein, L. (1953), Philosophical Investigations, Oxford: Basil Blackwell.

Wittgenstein, L. (1979), Notebooks 1914-1916, G. E. M. Anscombe and G. H. von Wright (eds.), Chicago: Chicago University Press.

Wittgenstein, L. (1980), Culture and Value, Oxford: Basil Blackwell.

Wittgenstein, L. (1993a), 'A Lecture on Ethics', in: Philosophical Occasions 1912-1951, J. Klagge \& A. Nordmann (eds.), Indianapolis: Hackett Publishing Company.

Wittgenstein, L. (1993b), 'Wittgenstein's Lectures in 1930-33', in: Philosophical Occasions 1912-1951, J. Klagge \& A. Nordmann (eds.), Indianapolis: Hackett Publishing Company.

Wittgenstein, L. (1993c), 'Remarks on Frazer's Golden Bough', in: Philosophical Occasions 1912-1951, J. Klagge \& A. Nordmann (eds.), Indianapolis: Hackett Publishing Company.

Wittgenstein, L. (1993d), 'Philosophy', in: Philosophical Occasions 1912-1951, (J. Klagge \& A. Nordmann (eds.), Indianapolis: Hackett Publishing Company.

Wittgenstein, L. (1993e), 'Notes for Lecture on "Private Experience" and "Sense Data"', in: Philosophical Occasions 1912-1951, J. Klagge \& A. Nordmann (eds.), Indianapolis: Hackett Publishing Company. 